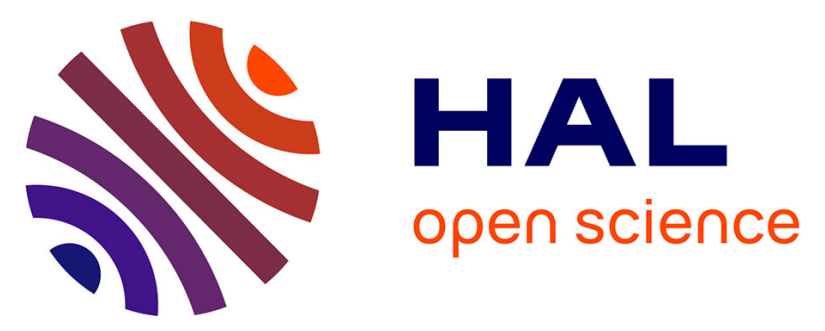

\title{
DHA-derived oxylipins, neuroprostanes and protectins, differentially and dose-dependently modulate the inflammatory response in human macrophages: putative mechanisms through PPAR activation
}

Rémy Bosviel, Laurie Joumard-Cubizolles, Giulia Chinetti-Gbaguidi, Dominique Bayle, Corinne Copin, Nathalie Hennuyer, Isabelle Duplan, Bart Staels, Giuseppe Zanoni, Alessio Porta, et al.

\section{- To cite this version:}

Rémy Bosviel, Laurie Joumard-Cubizolles, Giulia Chinetti-Gbaguidi, Dominique Bayle, Corinne Copin, et al.. DHA-derived oxylipins, neuroprostanes and protectins, differentially and dosedependently modulate the inflammatory response in human macrophages: putative mechanisms through PPAR activation. Free Radical Biology and Medicine, 2017, 103, pp.146-154. 10.1016/j.freeradbiomed.2016.12.018 . hal-01595235

\author{
HAL Id: hal-01595235 \\ https://hal.science/hal-01595235
}

Submitted on 3 Jun 2021

HAL is a multi-disciplinary open access archive for the deposit and dissemination of scientific research documents, whether they are published or not. The documents may come from teaching and research institutions in France or abroad, or from public or private research centers.
L'archive ouverte pluridisciplinaire $\mathbf{H A L}$, est destinée au dépôt et à la diffusion de documents scientifiques de niveau recherche, publiés ou non, émanant des établissements d'enseignement et de recherche français ou étrangers, des laboratoires publics ou privés. 


\title{
DHA-derived oxylipins, neuroprostanes and protectins, differentially and dose-dependently modulate the inflammatory response in human macrophages: Putative mechanisms through PPAR activation
}

\author{
Rémy Bosviel $^{\mathrm{a}, \mathrm{b}}$, Laurie Joumard-Cubizolles ${ }^{\mathrm{a}, \mathrm{b}}$, Giulia Chinetti-Gbaguidi ${ }^{\mathrm{c}, \mathrm{d}}$, Dominique Bayle ${ }^{\mathrm{a}, \mathrm{b}}$, \\ Corinne Copin ${ }^{c}$, Nathalie Hennuyer ${ }^{c}$, Isabelle Duplan ${ }^{c}$, Bart Staels ${ }^{c}$, Giuseppe Zanoni ${ }^{\mathrm{e}}$, \\ Alessio Porta ${ }^{\mathrm{e}}$, Laurence Balas ${ }_{\mathrm{f}}^{\mathrm{f}}$, Jean-Marie Galano ${ }^{\mathrm{f}}$, Camille Oger ${ }^{\mathrm{f}}$, Andrzej Mazur ${ }^{\mathrm{a}, \mathrm{b}}$, \\ Thierry Durand ${ }^{\mathrm{f}}$, Cécile Gladine ${ }^{\mathrm{a}, \mathrm{b}, *}$ \\ a INRA, UMR 1019, UNH, CRNH Auvergne, F-63000 Clermont-Ferrand, France \\ b Clermont Université, Université d'Auvergne, Unité de Nutrition Humaine, BP 10448, F-63000 Clermont-Ferrand, France \\ c Univ. Lille, Inserm, CHU Lille, Institut Pasteur de Lille, U1011, EGID, F-59000 Lille, France \\ ' University of Côte d'Azur, CHU, Inserm, CNRS, IRCAN, France \\ e University of Pavia, Pavia, Italy \\ ${ }^{\mathrm{f}}$ IBMM, UMR 5247 CNRS/UM/ENSCM, Montpellier, France
}

\section{A R T I C L E I N F O}

\section{Keywords:}

Omega 3 PUFAs

DHA

Oxylipins

Lipid mediators

Free-radical mediated oxygenation

Neuroprostanes

Protectins

Inflammation

PPARs

\begin{abstract}
A B S T R A C T
Whereas the anti-inflammatory properties and mechanisms of action of long chain $\omega 3$ PUFAs have been abundantly investigated, research gaps remain regarding the respective contribution and mechanisms of action of their oxygenated metabolites collectively known as oxylipins. We conducted a dose-dependent and comparative study in human primary macrophages aiming to compare the anti-inflammatory activity of two types of DHA-derived oxylipins including the well-described protectins (NPD1 and PDX), formed through lipoxygenase pathway and the neuroprostanes $\left(14-\mathrm{A}_{4 \mathrm{t}^{-}}\right.$and $\left.4-\mathrm{F}_{4 \mathrm{t}}-\mathrm{NeuroP}\right)$ formed through free-radical mediated oxygenation and expected to be new anti-inflammatory mediators. Considering the potential ability of these DHA-derived oxylipins to bind PPARs and knowing the central role of these transcription factors in the regulation of macrophage inflammatory response, we performed transactivation assays to compare the ability of protectins and neuroprostanes to activate PPARs. All molecules significantly reduced mRNA levels of cytokines such as IL- 6 and TNF- $\alpha$, however not at the same doses. NPD1 showed the most effect at $0.1 \mu \mathrm{M}(-14.9 \%, p<$ 0.05 for IL- 6 and $-26.7 \%, p<0.05$ for TNF- $\alpha$ ) while the three other molecules had greater effects at $10 \mu \mathrm{M}$, with the strongest result due to the cyclopentenone neuroprostane, $14-\mathrm{A}_{4 \mathrm{t}}$-NeuroP $(-49.8 \%, p<0.001$ and $-40.8 \%, p<0.001$, respectively). Part of the anti-inflammatory properties of the DHA-derived oxylipins investigated could be linked to their activation of PPARs. Indeed, all tested oxylipins significantly activated PPAR $\gamma$, with 14- $\mathrm{A}_{4 \mathrm{t}}$-NeuroP leading to the strongest activation, and NPD1 and PDX also activated PPAR $\alpha$. In conclusion, our results show that neuroprostanes and more especially cyclopentenone neuroprostanes have potent anti-inflammatory activities similar or even more pronounced than protectins supporting that neuroprostanes should be considered as important contributors to the anti-inflammatory effects of DHA.
\end{abstract}

\footnotetext{
Abbreviations: AP-1, activator protein 1; B94, TNFAIP2, TNF alpha induced protein 2; C/EBP, CCAAT-enhancer-binding protein; CCL, chemokine ligand; CEX-1, chemokine exodus

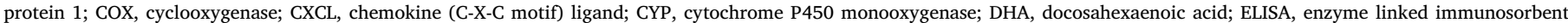

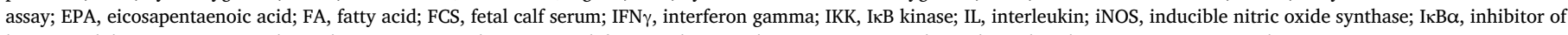

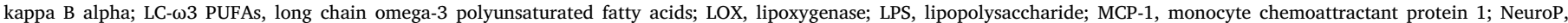

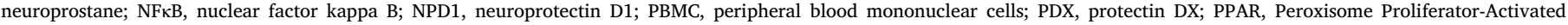
Receptor; PPRE, PPAR response element; sEH, soluble epoxyde hydrolase; STAT, signal transducer and activator of transcription; TNF- $\alpha$, tumor necrosis factor alpha

* Correspondence to: INRA, Centre INRA Auvergne Rhône Alpes, Site de Theix, UMR 1019, Unité de Nutrition HUmaine, 63 122 Saint Genès Champanelle, France.

E-mail addresses: remy.bosviel@gmail.com (R. Bosviel), laurie.cubizolles@udamail.fr (L. Joumard-Cubizolles), giulia.chinetti@unice.fr (G. Chinetti-Gbaguidi), dominique.bayle@inra.fr (D. Bayle), corinne.copin@pasteur-lille.fr (C. Copin), nathalie.hennuyer@pasteur-lille.fr (N. Hennuyer), isabelle.duplan@pasteur-lille.fr (I. Duplan),

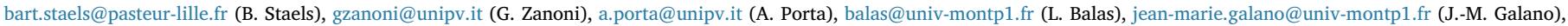
camille.oger@univ-montp1.fr (C. Oger), andre.mazur@inra.fr (A. Mazur), thierry.durand@umontpellier.fr (T. Durand), cecile.gladine@inra.fr (C. Gladine).
} 


\section{Introduction}

Evidences suggest that increased consumption of LC- $\omega 3$ PUFAs, notably DHA [1], reduces chronic inflammation and the incidence of inflammation-linked disorders such as atherosclerosis or metabolic syndrome $[1,2]$. The anti-inflammatory effects of LC- $\omega 3$ PUFAs include the decrease of immune cell chemotaxis, the inhibition of leukocytes/ endothelium adhesive interactions and the moderation of macrophage pro-inflammatory activity. For instance, several in vitro experiments with PBMC, neutrophils or monocytes isolated from the blood of healthy subjects consuming daily supplements of EPA and DHA showed significant reduction (up to $75 \%$ ) of leukotriene $\mathrm{B}_{4}$ chemoattractant production $[3,4]$. Ex-vivo treatment with LC- $\omega 3$ PUFAs has also been associated with reduced levels of several pro-inflammatory cytokines and chemokines including TNF- $\alpha$, IL- $1 \beta$, IL- 6 or MCP- 1 by approximately 40 to $80 \%$ in PBMC or mononuclear cells from healthy men or women supplemented with EPA and DHA daily for 4 weeks to up to 3 months [5-7]. The mechanisms of action underlying the anti-inflammatory properties of LC- $\omega 3$ PUFAs have been mostly linked to the altered activation of $\mathrm{NFKB}_{\mathrm{K}}$ [2], one of the main transcription factors regulating the expression of pro-inflammatory mediators [8]. This is notably mediated by the activation of PPAR $\alpha$ and PPAR $\gamma$ which physically interact with $\mathrm{NFKB}$ preventing its nuclear translocation [2]. Independently to NFKB, PPARs also directly modulate immune and inflammatory response in macrophages via protein/protein interactions with transcription factors controlling pro-inflammatory genes such as AP-1, C/EBP and STAT, a phenomenon called trans-repression. PPARs can also regulate transcription via trans-activation by binding, in a ligand-dependent manner, to DNA response elements (PPRE) in the promoter or enhancer regions of target genes $[9,10]$.

Whereas the biological properties and putative mechanisms of action of LC- $\omega 3$ PUFAs have been abundantly investigated, research gaps remain especially regarding the roles and mechanisms of action of their oxygenated metabolites collectively known as oxylipins. Oxylipins refer to a superclass of lipid mediators (hundreds of metabolites) produced from oxygenation of PUFAs. They include the prostanoids and thromboids produced by COXs, leukotrienes, resolvins, hepoxilins and mid-chain hydroxy-FA generated by LOXs, epoxy-FA and omegaterminal hydroxy-FA produced by several CYPs as well as iso/neuroprostanes resulting from the free-radical-mediated oxidation of PUFAs $[11,12]$. DHA in particular is not a good COX substrate but it is readily oxygenated by LOX, CYPs as well as free-radical mediated pathways giving rise to an array of oxylipins. From the LOX pathway, DHA gives rise to D serie resolvins, maresins and protectins via further LOX and epoxygenation steps. Protectin D1 is produced via LOX, epoxide formation from the hydroperoxide product and epoxide hydrolase activity while protectin DX is formed via double LOX activity [13]. DHA is also readily oxygenated via CYP epoxygenase activity, yielding epoxy FAs which can be converted to dihydroxy FAs via sEH. CYP vhydroxylase activity produces hydroxy-docosahexaenoic acid with hydroxyl groups near the methyl end of DHA [14]. Finally, because of its high number of double bonds, DHA is very prone to peroxidation yielding neuroprostanes which include a total of 128 theoretical compounds categorized into 8 regioisomers series $(4,7,10,11,13$, 14,17 or 20 ) among which levels of 4 - and 20 -series are predominant in vivo [15]. A large body of evidence suggests that oxylipins might be the effective mediators of the anti-inflammatory properties of EPA and DHA. The group of Sethi et al. was the first to demonstrate that the autooxidation of EPA and DHA (induced by ex-vivo oxidation of the native $\mathrm{FAs}$ with $\mathrm{CuSO}_{4}$ and ascorbic acid) was a mandatory prerequisite to induce a reduction of the adhesion of U937 monocytes to endothelial cells via a decreased expression of adhesion molecules [16]. More recently, enzymatic oxylipins derived from EPA and DHA (resolvins, protectins and maresins), have been examined extensively in cell culture and animal models of inflammation and have been identified as potent anti-inflammatory and inflammation resolving lipid mediators
[17]. Interestingly, several studies showed that LC- $\omega 3$ PUFA-derived oxylipins might act, at least in part, through PPAR dependent mechanisms [18-22] which is consistent with reporter assay and in silico studies showing that oxidized metabolites of PUFAs are good PPAR ligands $[23,24]$. Direct evidence regarding the biological activity and mechanisms of action of non-enzymatic oxylipins are much scarcer but a study performed by the group of Morrow as well as our previous results on atherosclerotic mice [25] also support the fact that the specific DHAderived oxylipins called neuroprostanes might also have anti-inflammatory activities through a mechanism involving NFKB [26] and PPARs [27].

In the present study, we focused our attention on oxylipins derived from DHA rather than EPA because of its more potent anti-inflammatory activity [1] and its higher susceptibility to produce the nonenzymatic oxylipin neuroprostanes [28] expected to be new antiinflammatory mediators of interest [17]. The main objectives of our study were (1) to compare, in human primary macrophages, the antiinflammatory properties of neuroprostanes to the well-described protectins and (2) to investigate the dose-response relationship. Moreover, since PPARs might be one of the multiple targets of oxylipins, we assessed the ability of the DHA-derived oxylipins to bind and activate PPARs using docking in silico tests and transient transfection assays.

\section{Materials and methods}

\subsection{Synthesis of DHA-derived oxylipins}

14- $\mathrm{A}_{4 \mathrm{t}}$-NeuroP, was synthesized by Dr. G. Zanoni's laboratory as previously described [29], 4-F $\mathrm{F}_{4 \mathrm{t}}$-NeuroP and NPD1 were synthesized by Dr. T. Durand's laboratory as previously described [30,31] while PDX was purchased from Cayman Chemical (via Bertin Pharma, Montigny le Bretonneux, France). Stock solutions $(20 \mathrm{mM})$ were prepared in ethanol and stored at $-80^{\circ} \mathrm{C}$.

\subsection{Cell culture}

\subsubsection{Human primary monocyte-derived macrophages}

Mononuclear cells were isolated from buffy coats from healthy donors (French Blood Service, Saint-Etienne, France) [32]. After Ficoll (GE Healthcare, ref: 17144002, Fisher Scientific, Illkirch-Graffenstaden, France) gradient centrifugation, the monocytes were suspended in RPMI 1640 medium containing gentamycin $(0.1 \mathrm{mg} / \mathrm{mL}$, Gibco, ref: 15710049, Fisher Scientific), glutamine (2 mM, Gibco, ref: 11500-626, Fisher Scientific) and 10\% decomplemented pooled human serum (ref: S4190-100, Dominique Dutscher, Brumath, France). Cells were cultured at a density of $3 \times 10^{6}$ cells/well in Corning ${ }^{\circledR}$ Primaria $^{\mathrm{TM}}$ 6-well plastic culture dishes (BD Falcon ${ }^{\mathrm{TM}}$, ref: 353846, Dominique Dutscher). Differentiation of monocytes into macrophages occurred spontaneously by adhesion of cells to the culture dish. Mature monocyte-derived macrophages were used for experiments after 7 days of culture. For treatment with the different DHA-derived oxylipins, medium was changed to RPMI 1640 medium containing gentamycin $(0.1 \mathrm{mg} / \mathrm{mL})$ and glutamine $(2 \mathrm{mM})$ (Gibco, Fisher Scientific) and different concentrations of oxylipins (i.e. $0.1,1$ or $10 \mu \mathrm{M}$ ) were added. According to the literature reporting short half-lives of oxylipins (in the range of seconds) and their relative instability in cell culture medium [26] and based on our preliminary results (data not shown), the DHA-derived oxylipins were added to the macrophages $30 \mathrm{~min}$ before the induction of inflammatory response with LPS (100 ng/mL, 6 h, ref: L2654, SigmaAldrich, Saint Quentin Fallavier, France). As eicosanoids may rapidly react with albumin [33], serum-free medium was used in these steps. At the end of the treatments, supernatants were harvested for ELISA and cells were processed for RNA extraction.

\subsubsection{Cos-7 cells}

To demonstrate the ability of the DHA-derived oxylipins to activate 
PPARs, COS-7 cells, a cell model that can be easily and reproducibly transfected and that is more robust than primary macrophages, has been used. Cos-7 cells, obtained from ATCC (CRL-1651, LGC Standards, Molsheim, France) were seeded in $60 \mathrm{~mm}$ dishes at a density of $5.5 \times 10^{5}$ cells/dish in DMEM medium (ref: 41965, Gibco, Fisher Scientific) supplemented with $10 \%$ fetal calf serum (FCS, ref: SV30160.03, Hyclone, GE Healthcare Life Sciences, Fisher Scientific) and incubated at $37^{\circ} \mathrm{C}, 5 \% \mathrm{CO}_{2}$ for $16 \mathrm{~h}$ prior to transfection. Cells were transfected in DMEM medium, using jetPEI transfection reagent (ref: 101-10, Polyplus, Ozyme, Saint Quentin Yvelines, France), with reporter (pG5-TK-pGL3) and pGal4-hPPAR $\alpha, \mathrm{pGal4-hPPAR \gamma}$ or pGal4hPPAR $\delta$ expression plasmids constructed as previously described [34]. Briefly, hPPAR domains were subcloned in the plasmid pBD-Gal4 and the obtained chimera was subcloned in the pCDNA vector. The pCMV$\beta$-galactosidase expression plasmid (ref: 631719, Clontech, Ozyme) was co-transfected as a control for transfection efficiency. After $16 \mathrm{~h}$, transfection was stopped by addition of DMEM medium supplemented with $10 \%$ FCS and cells were then trypsinized, seeded in 96 wells plates and then incubated overnight in DMEM medium without FCS containing increasing concentrations $(0.1-20 \mu \mathrm{M})$ of $14-\mathrm{A}_{4 \mathrm{t}^{-}}$-NeuroP, $4-\mathrm{F}_{4 \mathrm{t}^{-}}$ NeuroP, NPD1, PDX or vehicle (DMSO). WY 14.643 (10 $\mu$ M, Chemsyn Science Laboratories, Lenexa, KS, USA), Rosiglitazone ( $1 \mu \mathrm{M}$, SigmaAldrich) and GW 501516 ( $1 \mu \mathrm{M}$, Calbiochem, Merck, Fontenay sous Bois, France) were used as positive control of PPAR $\alpha, \operatorname{PPAR} \gamma$ and PPAR $\delta$ activation [35-37].

respectively. At the end of the experiment, cells were washed once with ice-cold PBS, lysed and luciferase and $\beta$-galactosidase assays were performed as previously described [38].

\subsection{RNA extraction and analysis}

Total cellular RNA was extracted from macrophages using Trizol reagent (ref: 12044977, Fisher Scientific) following the instructions of the manufacturer. For qRT-PCR analysis of TNF- $\alpha$, IL-6, COX-2, MCP-1 and CCL-3 expression, total RNAs were submitted to DNAse treatment using the Thermo Scientific RNAse free DNAse I kit (ref: 10649890, Fisher Scientific), according to manufacturer's instructions, reverse transcribed (RT) using Applied Biosystems ${ }^{\mathrm{TM}}$ High-Capacity cDNA Reverse Transcription Kit (ref: 10400745, Fisher Scientific) and subsequently amplified by real-time quantitative polymerase chain reaction (qPCR) on an AB 7900 apparatus (Applied Biosystems) using specific primers (Table 1) and Agilent Technologies Brilliant III ultra FAST kit (ref: 600882, Agilent Technologies, Les Ulis, France) with a $60{ }^{\circ} \mathrm{C}$ elongation temperature. The relative expression of each gene was normalized to the expression level of cyclophilin and calculated by the $\Delta \mathrm{C}_{\mathrm{t}}$ method. The $\Delta \mathrm{C}_{\mathrm{t}}$ is expressed as the difference between the $\mathrm{C}_{\mathrm{t}}$ (threshold cycle) of the indicated target gene and the $\mathrm{C}_{\mathrm{t}}$ of cyclophilin. The amount of target gene relative to the cyclophilin was expressed as $2^{-(\Delta \Delta \mathrm{Ct})}$.

\subsection{ELISA test}

MCP-1 and TNF- $\alpha$ secreted in cell culture supernatants were quantified using enzyme linked immunosorbent assays (ELISA) purchased from R \& D Systems (DY279 and DY210, respectively, Abingdon,
UK) according to the instructions of the manufacturer.

\subsection{Statistical analysis}

Data are presented as mean \pm standard deviation (SD). Comparisons between groups were analyzed using Student's $t$-test and statistical significance was established at $p<0.05$. For gene expression and ELISA assays, all conditions were compared to vehicle $30 \mathrm{~min}$, LPS $6 \mathrm{~h}$ experimental condition. For PPAR transfection assays, all conditions were compared to vehicle treated cells.

\section{Results}

The anti-inflammatory effects of the four DHA-derived oxylipins (i.e. the non-enzymatic $14-\mathrm{A}_{4 \mathrm{t}}-\mathrm{NeuroP}, 4-\mathrm{F}_{4 \mathrm{t}}$-NeuroP and the enzymatic PDX and NPD1), were evaluated by analyzing the expression and secretion of selected pro-inflammatory markers in primary human monocyte-derived macrophages after a $6 \mathrm{~h}$ treatment with LPS $(100 \mathrm{ng} / \mathrm{mL}$ ). As expected, LPS induced drastic increases (compared to control vehicle treated cells) of all markers, at the mRNA (TNF- $\alpha$ : $\times 92, p<0.001$; IL-6: $\times 819, p<0.001$; MCP- $1: \times 9, p<0.001$; COX2: $\times 182, p<0.001$; CCL-3: $\times 47, p<0.001$ ) and protein $($ TNF- $\alpha:$ $\times 70.0, p<0.001$ and MCP-1: $\times 3.7, p<0.01$ ) levels.

\subsection{Dose-dependent effects of DHA-derived oxylipins on mRNA levels of pro-inflammatory markers}

In order to investigate the ability of DHA-derived oxylipins to modulate the inflammatory response induced by LPS, monocytederived macrophages were pre-incubated with the DHA-derived oxylipins ( $30 \mathrm{~min}$ ) before LPS-induced inflammation.

Results of gene expression obtained with the highest dose of DHAderived oxylipins (i.e. $10 \mu \mathrm{M}$ ) are showed in Fig. 1. Interestingly, the strongest effects were obtained with the cyclopentenone neuroprostane, $14-\mathrm{A}_{4 \mathrm{t}}$-NeuroP, which caused substantial decreases of IL-6 $(-49.8 \%, p$ $<0.001)$, TNF- $\alpha(-40.8 \%, p<0.001)$, MCP-1 $(-58.8 \%, p<0.001)$, CCL-3 $(-21.7 \%, p<0.01)$ and COX-2 $(-26.7 \% p<0.01)$ mRNA. The other neuroprostane, 4- $\mathrm{F}_{4 \mathrm{t}}$-NeuroP, also reduced mRNA levels of IL-6 $(-30.6 \%, p<0.01)$, TNF- $\alpha(-18.9 \%, p<0.05)$ and MCP-1 $(-34.2 \%$, $p<0.01$ ). Concerning the enzymatic oxylipins, pre-incubation with PDX significantly decreased IL- $6(-42.9 \%, p<0.05)$, TNF- $\alpha(-52.3 \%$, $p<0.05)$ and MCP-1 $(-54.2 \%, p<0.05)$ whereas NPD1 had no significant effect on the mRNA levels of all tested pro-inflammatory markers.

At lower doses (i.e. 0.1 and $1 \mu \mathrm{M}$ ), the DHA-derived oxylipins had less pronounced effects on mRNA expression except for NPD1 (Table 2). More precisely, at $1 \mu \mathrm{M}$ concentration, 4- $\mathrm{F}_{4 \mathrm{t}}$-NeuroP reduced IL-6 $(-24.5 \%, p<0.05)$ while NPD1 and PDX reduced CCL3 $(-30.4 \%$ and $-25.6 \%, p<0.05$, respectively). With $0.1 \mu \mathrm{M}$ doses, $14-\mathrm{A}_{4 \mathrm{t}^{-}}$ NeuroP reduced MCP-1 mRNA $(-23.8 \%, p<0.001)$ and NPD1, that was inactive at $10 \mu \mathrm{M}$, showed important effects with reduced IL-6 $(-14.9 \%, p<0.05)$, TNF- $\alpha(-26.7 \%, p<0.05)$ and COX-2 $(-38.7 \%$, $p<0.05)$ mRNA.

Table 1

List of primers used for mRNA analysis.

\begin{tabular}{|c|c|c|}
\hline Target mRNA & Primer forward (5' to $3^{\prime}$ ) & Primer reverse (5' to $\left.3^{\prime}\right)$ \\
\hline Cyclophilin & GCATACGGGTCCTGGCATCTTGTCC & ATGGTGATCTTCTTGCTGGTCTTGC \\
\hline IL-6 & AAGTCCTGATCCAGTTCCTG & GATGAGTTGTCATGTCCTGC \\
\hline TNF- $\alpha$ & CAGAGGGCCTGTACCTCATC & GGAAGACCCCTCCCAGATAG \\
\hline MCP-1 & TCATAGCAGCCACCTTCATTCC & GGACACTTGCTGCTGGTGATTC \\
\hline COX-2 & TGAGCATCTACGGTTTGCTG & TGCTTGTCTGGAACAACTGC \\
\hline CCL-3 & TGCAACCAGTTCTCTGCATC & TTTCTGGACCCACTCCTCAC \\
\hline
\end{tabular}



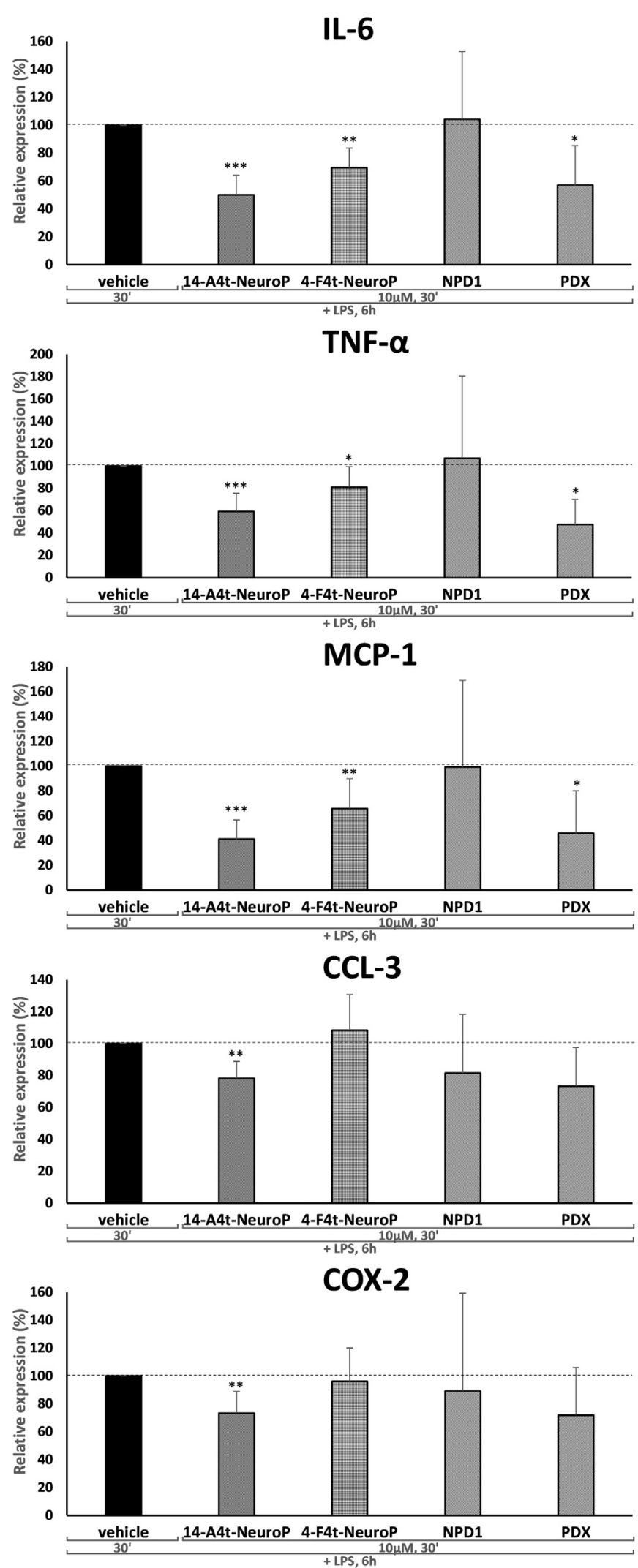

Fig. 1. Percentage of IL-6, TNF- $\alpha$, MCP-1, CCL-3 and COX-2 mRNA levels in human monocyte-derived macrophages pre-exposed for $30 \mathrm{~min}$ with $10 \mu \mathrm{M}$ of $14-\mathrm{A}_{4 \mathrm{t}} \mathrm{-NeuroP}$, 4$\mathrm{F}_{4 \mathrm{t}}$-NeuroP, NPD1 or PDX before the induction of inflammatory response with LPS $(100 \mathrm{ng} / \mathrm{mL}, 6 \mathrm{~h})$, in comparison with macrophages pre-exposed to vehicle alone. Results are means of at least 5 independent experiments using cells from different donors. Student's $t$-test (comparison to vehicle $30 \mathrm{~min}$, LPS $6 \mathrm{~h}$ condition). ${ }^{*} p<0.05 ; * * p<$ $0.01 ; * * * p<0.001$.

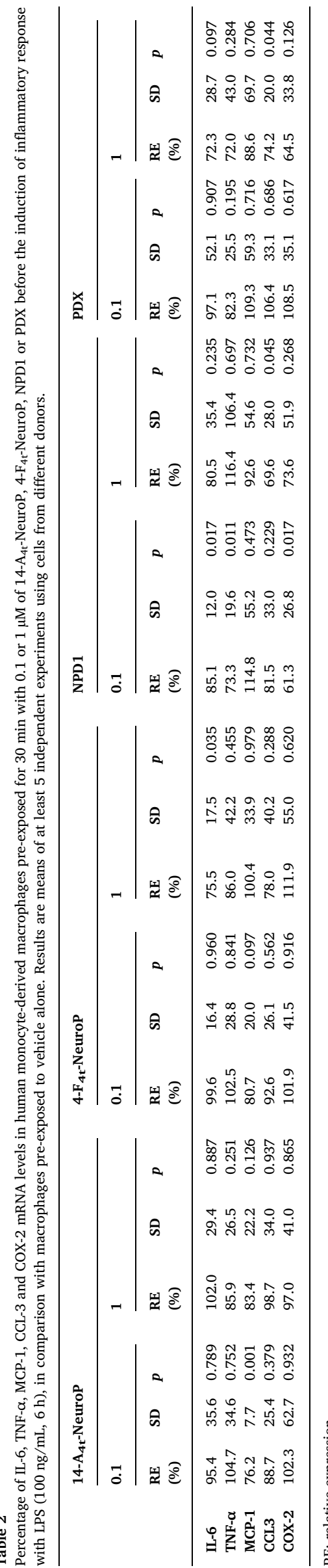



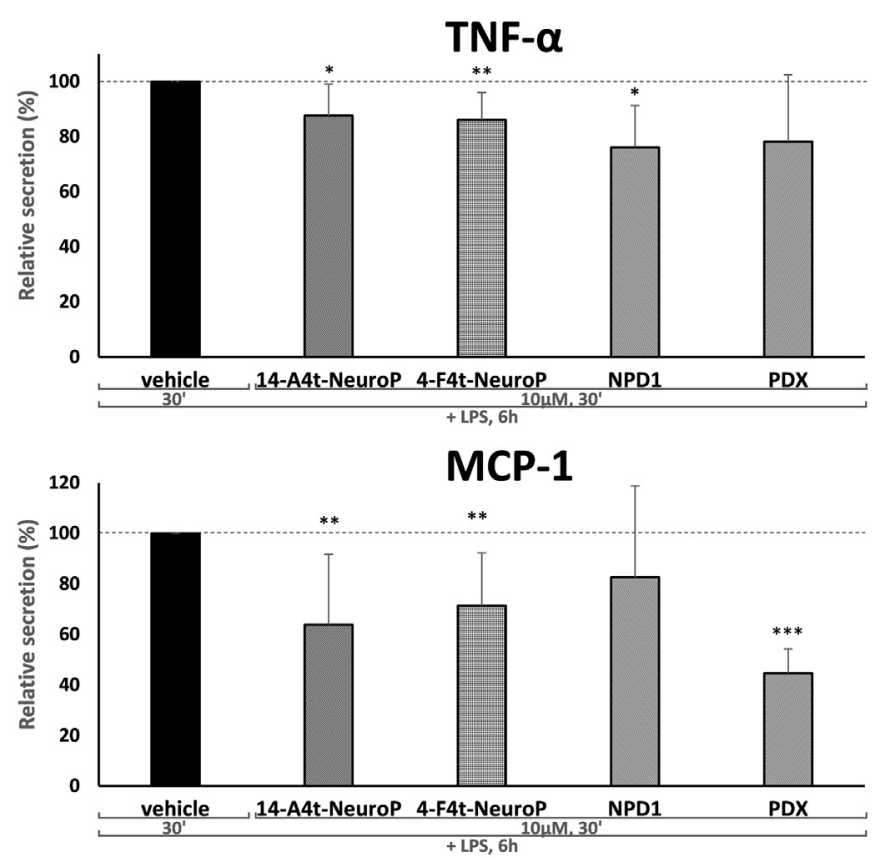

Fig. 2. Percentage of TNF- $\alpha$ and MCP-1 secreted protein levels by human monocytederived macrophages pre-exposed for $30 \mathrm{~min}$ with $10 \mu \mathrm{M}$ of $14-\mathrm{A}_{4 \mathrm{t}}-\mathrm{NeuroP}, 4-\mathrm{F}_{4 \mathrm{t}}$-NeuroP, NPD1 or PDX before the induction of inflammatory response with LPS $(100 \mathrm{ng} / \mathrm{mL}, 6 \mathrm{~h})$, in comparison with macrophages pre-exposed to vehicle alone. Results are means of at least 5 independent experiments using cells from different donors. Student's $t$-test (comparison to vehicle $30 \mathrm{~min}$, LPS $6 \mathrm{~h}$ condition). * $p<0.05$; ** $p<0.01$; *** $p<$ 0.001 .

3.2. Dose-dependent effects of DHA-derived oxylipins on the secretion of TNF- $\alpha$ and MCP-1

ELISA assays were used to investigate the effects of the four DHAderived oxylipins on LPS-induced secretion of two main pro-inflammatory cytokines and chemokines, i.e. TNF- $\alpha$ and MCP-1. Overall, it should be noted that the effects at the protein level (Fig. 2) for TNF- $\alpha$ were less pronounced than the effects described above at the mRNA level. However, consistently with the previous results, both $14-\mathrm{A}_{4 \mathrm{t}^{-}}$ NeuroP and $4-\mathrm{F}_{4 \mathrm{t}}-\mathrm{NeuroP}$ at $10 \mu \mathrm{M}$ reduced TNF- $\alpha$ secretion $(-12.4 \%$, $p<0.05 ;-13.9 \%, p<0.01)$. Surprisingly, NPD1 also induced a significant decrease of TNF- $\alpha$ secretion $(-23.9 \%, p<0.05)$ and PDX had no effect. At lower concentration, none of the DHA-derived oxylipins induced significant decrease of TNF- $\alpha$ secretion (Table 3).

Effects of the four DHA-derived oxylipins on MCP-1 protein levels matched those on mRNA level for the $10 \mu \mathrm{M}$ dose: $14-\mathrm{A}_{4 \mathrm{t}^{-}}-\mathrm{NeuroP}, 4-\mathrm{F}_{4 \mathrm{t}^{-}}$ NeuroP and PDX reduced MCP-1 secretion $(-36.1 \%, p<0.01$; $-28.5 \%, p<0.01$ and $-55 \%, p<0.001$ respectively).

At lower concentrations however, only PDX induced significant decreases of MCP-1 secretion, with a $-39.5 \%(p<0.05)$ reduction at $1 \mu \mathrm{M}$ and a $-56 \%(p<0.01)$ reduction at $0.1 \mu \mathrm{M}$ (Table 3$)$.

\subsection{Ability of DHA-derived oxylipins to bind to and activate PPARs}

Activation of the PPARs is one of the three mechanisms through which LC- $\omega 3$ PUFAs potentially exert their anti-inflammatory properties [2] and several studies suggest that LC- $\omega 3$ PUFA-derived oxylipins might activate PPARs [18-22].

To assess whether 14- $\mathrm{A}_{4 \mathrm{t}}-\mathrm{NeuroP}, 4-\mathrm{F}_{4 \mathrm{t}}-\mathrm{NeuroP}, \mathrm{NPD} 1$ and PDX are effective PPAR ligands, transient transfections of a luciferase reporter vector with hPPAR $\alpha$, hPPAR $\gamma$ or hPPAR $\delta$ expression vectors were performed in Cos-7 cells. In all experiments, the agonists of the tested receptor, i.e. respectively WY $14.643(10 \mu \mathrm{M})$, rosiglitazone $(1 \mu \mathrm{M})$ and GW501516 $(1 \mu \mathrm{M})$, drastically induced the transcriptional activity of luciferase reporter vector in Cos-7 cells $\left(\times 1.4 \times 10^{18}, p<0.001\right.$;

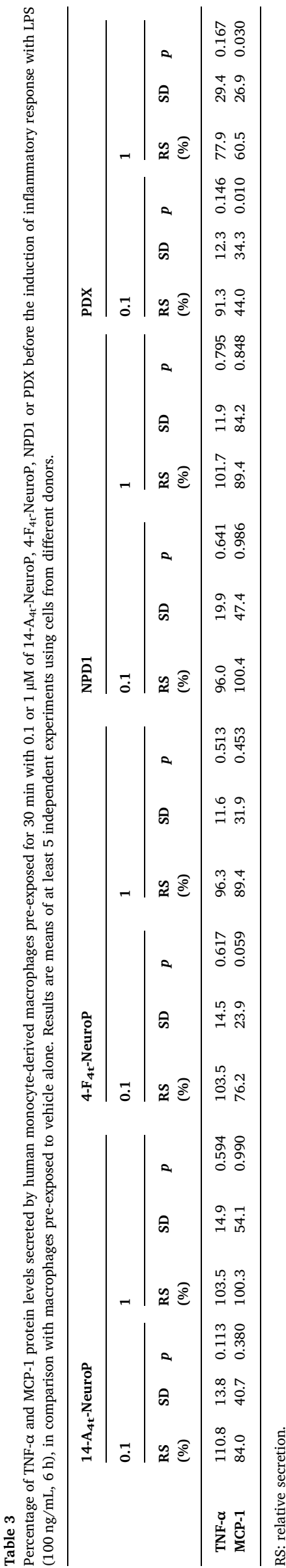



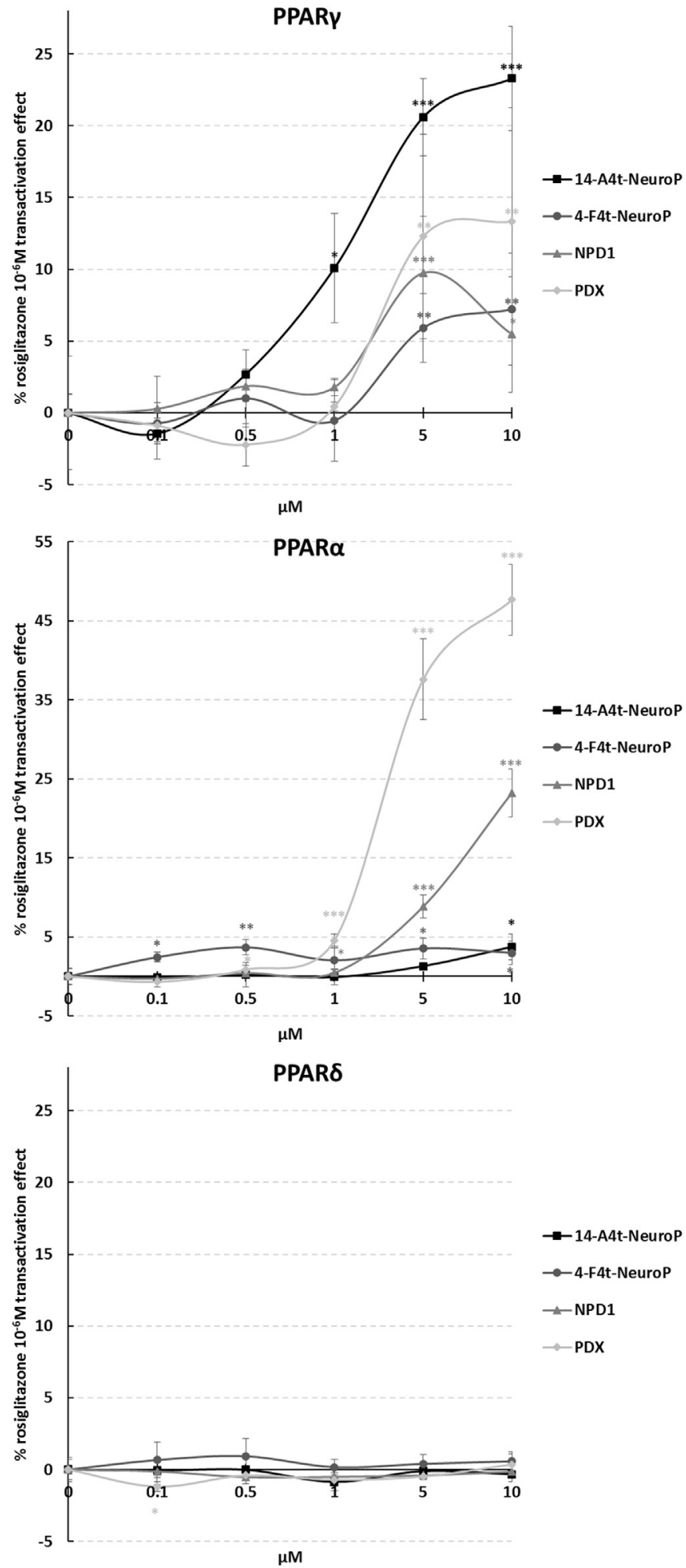

Fig. 3. Induction of luciferase activity by pGal4/hPPAR $\alpha$, pGal4/hPPAR $\gamma$ or pGal4/ hPPAR $\delta$ constructs in Cos-7 cells (reported as a percentage of the induction found with WY14.643 $10^{-5} \mathrm{M}$, rosiglitazone $10^{-6} \mathrm{M}$ or GW501516 $10^{-6} \mathrm{M}$, respectively) exposed to varying concentrations of $14-\mathrm{A}_{4 \mathrm{t}}-\mathrm{NeuroP}, 4-\mathrm{F}_{4 \mathrm{t}}-\mathrm{NeuroP}$, NPD1 and PDX. Experiments were performed in triplicates. Student's $t$-test (compared to vehicle condition). ${ }^{*} p<0.05$; $* * p<0.01 ; * * * p<0.001$.

$\times 2.2 \times 10^{17}, p<0.001$ and $\times 6.4 \times 10^{17}, p<0.001$, respectively)

All assayed oxylipins led to the induction of the transcriptional activity of luciferase reporter vector in Cos-7 cells transfected with the hPPAR $\gamma$ expression vector (Fig. 3). 14- $\mathrm{A}_{4 \mathrm{t}}$-NeuroP showed again the most effect with significant induction at 1,5 and $10 \mu \mathrm{M}$, attaining a maximum, equivalent to $23.3 \%$ of the induction obtained with $1 \mu \mathrm{M}$ rosiglitazone. Lower inductions were obtained when Cos-7 cells were treated with 4- $\mathrm{F}_{4 \mathrm{t}}$-NeuroP, NPD1 and PDX (with maximal induction representing $7.2 \%, 5.5 \%$ and $13.3 \%$ of $1 \mu \mathrm{M}$ rosiglitazone activation, respectively) and were significant only at 5 and $10 \mu \mathrm{M}$.

In experiments using the hPPAR $\alpha$ expression vector, 14- $\mathrm{A}_{4 \mathrm{t}}$-NeuroP only induced slightly the transcriptional activity of luciferase at $10 \mu \mathrm{M}$ (3.8\% of the induction obtained with WY 14.643). Similar inductions were detected with $0.1,0.5,5$ and $10 \mu \mathrm{M}$ 4-F4t-NeuroP, with a maximum induction of $3.0 \%$. Interestingly, PDX showed dose-response activation with significant effects starting at $0.5 \mu \mathrm{M}$ and a maximum of $47.7 \%$ induction for $10 \mu \mathrm{M}$. Finally, lower, but still important doseresponse effects were observed with NPD1, with significant induction at 1,5 and $10 \mu \mathrm{M}$, attaining a maximum of $23.2 \%$ induction. However, no induction was seen for any treatment with the tested oxylipins in cells transfected with the hPPAR $\delta$ vector.

\section{Discussion}

A large body of evidence suggests that LC- $\omega 3$ PUFAs might exert a part of their anti-inflammatory activities via their corresponding oxylipins. While enzymatic DHA-derived oxylipins, i.e. the protectins, resolvins and maresins, have been extensively investigated in the last decade (see [17] for a recent review), data regarding non-enzymatic species, i.e. the neuroprostanes, are scarce. In this comparative and dose-response study performed in human primary macrophages, we showed that the electrophilic cyclopentenone neuroprostanes were the most potent DHA-derived oxlipins tested, especially at the high doses $(10 \mu \mathrm{M})$. Interestingly, in our model, NPD1 had no effect at high dose $(10 \mu \mathrm{M})$ but became very active at the lowest dose $(0.1 \mu \mathrm{M})$ whereas the other oxylipins tested lost most of their effects at low doses. The other major results of this study are related to the PPARs transfection experiments showing for the first time that (1) cyclopentenone neuroprostanes activate PPAR $\gamma,(2)$ cyclopentenone neuroprostanes activate PPAR $\gamma$ stronger than the protectins and (3) NPD1 and even more PDX preferentially activate PPAR $\alpha$.

\subsection{Anti-inflammatory activity of the DHA-derived oxylipins}

Macrophages are able to convert DHA to a large array of oxylipins such as D-serie resolvins, protectins, maresin as well as hydroy and epoxy FA and neuroprostanes which are suggested to have complex interactions to drive to inflammatory response and promote the resolution of inflammation. For instance, NPD1/PD1 biological actions have been extensively studied [39]. NPD1 regulates leukocyte infiltration, increases macrophage phagocytosis and regression from the inflammation site [40]. NPD1, resolvin D1, and 14,21-diHDHA accelerate wound healing and 14S,21RdiHDHA recovers the reparative functions of macrophages from diabetic mice [41]. In the present experiment, attention was focused on neuroprostanes and their antiinflammatory activity which was compared to the LOX-derived protectins. All DHA-derived oxylipins investigated had an anti-inflammatory activity with $14-\mathrm{A}_{4 \mathrm{t}}-\mathrm{NeuroP}, 4-\mathrm{F}_{4 \mathrm{t}}-\mathrm{NeuroP}$ and PDX being active at $10 \mu \mathrm{M}$ while NPD1 had significant effects on mRNA expression of proinflammatory markers at $0.1 \mu \mathrm{M}$. More precisely, among the four oxylipins tested, the cyclopentenone neuroprostane (i.e.14- $\mathrm{A}_{4 \mathrm{t}^{-}}$ NeuroP) was the most potent, inducing substantial (up to $58.8 \%$ ) reduction of all pro-inflammatory markers assessed. These results are consistent with the previous study conducted with this type of neuroprostane by the group of Morrow [26] who reported significant decreases of the pro-inflammatory markers iNOS and COX-2 in RAW 264.7 macrophages pre-exposed to $10 \mu \mathrm{M} 14-\mathrm{A}_{4}$-NeuroP. In this murine macrophage cell line, the authors also reported significant effects with a lower dose of 14- $\mathrm{A}_{4}$-NeuroP $(1 \mu \mathrm{M})$ on the expression of iNOS but not on COX-2. Altogether, the results obtained in our model bring more 
evidence that $14-\mathrm{A}_{4 \mathrm{t}}$-NeuroP has anti-inflammatory properties and extend the findings of Musiek et al. to humans. The other neuroprostane, the $4-\mathrm{F}_{4 \mathrm{t}}$-NeuroP, was also associated for the first time with significant anti-inflammatory properties. However, in comparison with the cyclopentenone neuroprostane, the $4-\mathrm{F}_{4 \mathrm{t}}$-NeuroP has less pronounced effect which might be due to the absence of an electrophilic carbon limiting its interaction with signaling proteins [42]. These in vitro results nevertheless support preliminary results obtained in $\mathrm{LDLR}^{-/-}$mice in which we showed that $\mathrm{F}_{4}$-NeuroPs were associated with reduced atherosclerosis [25], associated with a decreased inflammation [27]. Apart from those anti-inflammatory properties, 4- $\mathrm{F}_{4 \mathrm{t}^{-}}$ NeuroP has recently been shown to exert antiarrhythmic effect in mouse cardiomyocytes at doses ranging from $10 \mathrm{nM}$ to $1 \mu \mathrm{M}$ [43]. To the best of our knowledge, this is the only other in vitro study reporting biological activities of the $\mathrm{F}_{4}$-neuroprostanes.

In our model, PDX induced similar decrease of pro-inflammatory mediators than the $14-\mathrm{A}_{4 \mathrm{t}}$-NeuroP at $10 \mu \mathrm{M}$, but results were more variable and therefore less significant. A previous recent study performed in palmitate stimulated J774A.1 mouse macrophages reported decrease of proteins levels (in the range of about 25\%) for MCP1 , TNF- $\alpha$ and IL- 6 but also CCL-5, IL-2, iNOS and -more surprisingly- IL10 [44]. It should be noted that these effects were observed with lower doses of PDX (10 and $100 \mathrm{nM})$. Two other in vitro studies using different cell models found out that PDX could reduce COX-2 activity in human platelets [45] and in LPS-induced human neutrophils [46]. Several in vivo experiments also support the anti-inflammatory properties of PDX which has been showed for instance to reduce the levels of TNF- $\alpha$ and IL-6, but also IL-1 $\beta$, CXCL-1, CXCL-2 and NOS-2 by around $50 \%$ in the colon of PHIL mice that are specifically devoid of eosinophils challenged with dextran sodium sulfate and injected with $0.05 \mathrm{mg} / \mathrm{kg}$ of PDX [47]. In this study, the injection of PDX was also associated with a reduction of neutrophil infiltration in the colon and the inhibition of chemotaxis by PDX was also reported in a mice model of acute lung injury [48]. Concerning NPD1, in our model of human primary macrophages, it had no significant effect at high dose $(10 \mu \mathrm{M})$ on any of the pro-inflammatory markers investigated but it induced significant decreases at lower doses, with up to $38.7 \%$ reduction of mRNA levels of IL-6, TNF- $\alpha$ and COX-2 at $0.1 \mu \mathrm{M}$ and of CCL-3 at $1 \mu \mathrm{M}$. Among the four studied oxylipins, NPD1 is by far the most studied, with clear indications of its anti-inflammatory properties whereas it has never been investigated in human primary macrophages. Consistently with our findings, NPD1, at doses ranging from 0.1 to $200 \mathrm{nM}$, reduced from about $25-100 \%$ different types of pro-inflammatory markers (TNF- $\alpha$, IL-6, COX-2, IL1- $\beta$, IFN $\gamma$, CEX-1 and B94) in mouse macrophages $[40,41]$, in rat macrophages [49], in human peripheral blood T cells [50], in primary human neuro-glial cells [22], in human glioma cells [51] or in human neuron cells [52]. In vivo, application of drops of NPD1 solution, $300 \mathrm{ng} 2$ times per day during 6 days or injection of 50 ng NPD1 per day during 5 days, topically reduced pro-inflammatory markers (between around $30 \%$ and $90 \%$ inhibition of IL-6, CXCL-1, CXCL-10 and CCL-20 or around 50\% inhibition of TNF- $\alpha$ ) in herpes simplex virus-infected mouse corneas [53] or diabetic mouse wound tissue [41], respectively. To our knowledge, higher (micromolar) doses had never been studied before in vitro and our finding with 1 and $10 \mu \mathrm{M}$ NPD1 treatments are therefore not comparable to other studies. The anti-inflammatory properties of NPD1 were associated with reduction of neutrophil infiltration in vivo, in brain tissue from an ischemiareperfusion mouse model [54], in herpes simplex virus-infected mouse corneas [53], in rabbit wounded cornea [55], in mouse induced peritonitis $[39,40,50]$ or in kidneys from ischemia/reperfusion mouse models [49] and in vitro, with human neutrophils through monolayers of human microvascular endothelial cells [39].

As stated above, the four DHA-derived oxylipins tested in this study had different effects depending on the dose used. More precisely, 14$\mathrm{A}_{4 \mathrm{t}}$-NeuroP, 4- $\mathrm{F}_{4 \mathrm{t}}$-NeuroP and PDX showed most effects on regulating pro-inflammatory genes only at the highest dose tested $(10 \mu \mathrm{M})$ suggesting threshold type of response with the absence of effect at low dose and an effect proportional to the dose for doses over the threshold [56]. On the contrary, NPD1 showed a different type of response with higher activity for the lowest dose tested while it becomes inactive at higher dose therefore following an inverted $U$ shape dose response in agreement with the hormesis hypothesis. It is known that NPD1 stereoselectively and specifically binds with retinal pigment epithelial cells and neutrophils, suggesting the presence of specific receptors for NPD1 in both the immune and visual systems [57]. While the exact NPD1 receptor(s) have to be identified [58], one can indeed imagine that the absence of effect of NPD1 at high dose might be due to receptor desensitization or receptor over-saturation. Although more data would be necessary to understand completely these dose-responses, these results clearly show that different oxylipins may have the most beneficial effect at very different doses, thus pointing towards actions in different biological contexts or at different timing.

Altogether, this comparative and dose-response study strongly supports that neuroprostanes and more especially cyclopentenone neuroprostanes should be considered as major contributors of the anti-inflammatory effect of DHA. Whereas their anti-inflammatory action was mostly achieved at high dose, one might imagine that the oxidative burst associated to the first steps of the inflammatory response of macrophages could transiently generate high amount of neuroprostanes at the intracellular level. On the contrary, the fact that NPD1 was only active at low doses suggests a more subtle and enzymatically regulated activity consistent with its involvement in the resolution phase of inflammation [40].

\subsection{PPAR activation by the DHA-derived oxylipins}

The mechanisms of action underlying the anti-inflammatory effects of LC- $\omega 3$ PUFAs are mostly associated with an inhibition of the NFkB pathway notably through PPAR $\gamma$ dependent mechanisms. Many studies also report that oxylipins could be potent PPAR ligands $[23,24]$ which, together with the central role of PPARs in the regulation of inflammation and immunity in macrophage [9], strongly encouraged us to specifically investigate the ability of the DHA-derived oxylipins to bind and activate PPARs This was done using transactivation assays in Cos-7 cells which are commonly used to study the mechanisms of action of biomolecules through PPAR activation notably in the field of oxylipins $[18,21,22]$.

Our results showed that the four tested DHA-oxylipins were all able to bind and activate PPAR $\alpha$ and PPAR $\gamma$ (but not PPAR $\delta$ ) with different potency depending on the sub-type of PPAR and the oxylipins. Results concerning PDX and NPD1 are in good agreement with previous studies using reporter assays in transfected cells [21,22]. It should nevertheless be noted that significant activation were observed with lower doses of PDX and NPD1 which could be due to the difference in the sensitivity of the assays, with $1 \mu \mathrm{M}$ of rosiglitazone used in our case versus $0.1 \mu \mathrm{M}$ rosiglitazone in the one of White et al. [21]. Concerning the neuroprostanes, to our knowledge, these results are the first to demonstrate a direct link between $4-\mathrm{F}_{4 \mathrm{t}}$-NeuroP or $14-\mathrm{A}_{4 \mathrm{t}}$-NeuroP and PPAR $\gamma$ activation. Only one other study indirectly investigated the relationship between 14- $\mathrm{A}_{4 \mathrm{t}}$-NeuroP and PPAR $\gamma$ using RAW macrophages and inhibitors of PPAR but failed to confirm the contribution of PPAR $\gamma$ in the anti-inflammatory action of 14- $\mathrm{A}_{4 \mathrm{t}}$-NeuroP [26].

Interestingly, neuroprostanes preferentially activate PPAR $\gamma$ while the enzymatic oxylipins PDX and NPD1 activated preferentially PPAR $\alpha$. This difference of ligand potency could be due the differences of structure between these oxylipins. Indeed, although the large binding pocket of PPAR $\gamma$ allows for high versatility of potential ligands, differences in the detailed stereochemistry of said potential ligands lead to different potential to form hydrogen bonds or covalent bonds with the binding pocket and thus differences in affinity [24].

Altogether, results of the transactivation assays suggest that the anti-inflammatory activity previously described could be mediated, at 
least in part, through the binding of the DHA-derived oxylipins to PPAR $\alpha$ and PPAR $\gamma$. Through trans-repression, activated PPARs have shown potential to inhibit I $\mathrm{\kappa B} \alpha$ degradation, reduce p65 nuclear translocation or its binding to DNA $[59,60]$. Combined with transactivation mechanism this will lead to the regulation of multiple signaling pathways such as cholesterol homeostasis, but also the regulation of the immune response and inflammation.

The highest capacity of $14-\mathrm{A}_{4 \mathrm{t}}-\mathrm{NeuroP}$ to activate PPAR $\gamma$ probably contributes to explain its highest anti-inflammatory activity in monocyte-derived macrophages. This could also be due to the ability of 14$\mathrm{A}_{4 \mathrm{t}}$-NeuroP to directly inhibit NFKB through the inactivation of IKK as showed by Musiek et al. [26]. More precisely, the authors showed that 14- $\mathrm{A}_{4}$-NeuroP lost its capacity to inhibit LPS-induced nitrite production in RAW 264.7 macrophages after reduction of the carbonyl moiety on the cyclopentenone ring to a nonreactive alcohol. Musiek et al. also found out that a mutation of the cysteine 179 in the activation loop of IKK $\beta$ could prevent the IKK-dependent inhibition of IKB $\alpha$ phosphorylation triggered by $14-\mathrm{A}_{4}$-NeuroP. 14- $\mathrm{A}_{4}$-NeuroP may thus directly inhibit IKK function (and thus NFKB activation) through Michael adduction of this thiol. This action of cyclopentenone rings had already been found with other molecules such as cyclopentenone prostaglandins and cyclopentenone isoprostanes [61].

Although Cos-7 transactivation assay brought significant results, it should be noted that the DHA-derived oxylipins only partly activate PPAR $\alpha$ or PPAR $\gamma$ (maximum $25 \%$ or $45 \%$ of activation respectively for PDX/PPAR $\alpha$ and 14-A4-NeuroP/PPAR $\gamma$ ) which might not be physiologically relevant in non-artificial systems. Other complementary mechanisms of action should be investigated to further understand the observed anti-inflammatory properties of DHA-derived oxylipins.

\section{Conclusion}

In conclusion, our results show that neuroprostanes and more especially cyclopentenone neuroprostanes have significant anti-inflammatory activities similar or even more pronounced than protectins supporting that neuroprostanes should be considered as important contributors to the anti-inflammatory effects of DHA. Concerning the dose-response effect, it should be noted that the tested oxylipins had different effects depending on the doses. Notably, NPD1 was active for the lowest dose while it becomes inactive at higher dose suggesting a putative interaction with receptors and desensitization or receptor oversaturation at high dose. Transactivation assays suggested that at least part of the anti-inflammatory properties of the DHA-derived oxylipins investigated might be linked to PPARs whereas complementary mechanisms of action might also contribute to the effects observed. Combined together, these results bring new insights concerning the relative contribution and dose-dependent effect of different types of DHA-derived oxylipins including the non-enzymatic neuroprostanes recently suggested to be new mediators of interest [17]. The kinetics and cross-talks between the different types of oxylipins as well as a more detailed deciphering of the mechanisms of action of DHA-derived oxylipins would be valuable leads for further understanding the roles of oxylipins in the regulation of inflammation.

\section{Acknowledgements}

The authors would like to thank Severine Valero for her help in realizing ELISAs for this study.

Funding: This work was supported by intramural funding from INRA - Human nutrition department and the French Research on Lipids \& Nutrition Group (GLN).

\section{References}

[1] J. Allaire, P. Couture, M. Leclerc, A. Charest, J. Marin, M.-C. Lepine, D. Talbot, A. Tchernof, B. Lamarche, A randomized, crossover, head-to-head comparison of eicosapentaenoic acid and docosahexaenoic acid supplementation to reduce inflammation markers in men and women: the Comparing EPA to DHA (compared) study, Am. J. Clin. Nutr. 104 (2016) 280-287. http://dx.doi.org/10.3945/ ajcn.116.131896.

[2] P.C. Calder, Marine omega-3 fatty acids and inflammatory processes: effects, mechanisms and clinical relevance, Biochim. Biophys. Acta BBA - Mol. Cell Biol. Lipids 1851 (2015) 469-484. http://dx.doi.org/10.1016/j.bbalip.2014.08.010.

[3] T.H. Lee, R.L. Hoover, J.D. Williams, R.I. Sperling, J. Ravalese, B.W. Spur, D.R. Robinson, E.J. Corey, R.A. Lewis, K.F. Austen, Effect of dietary enrichment with eicosapentaenoic and docosahexaenoic acids on in vitro neutrophil and monocyte leukotriene generation and neutrophil function, N. Engl. J. Med. 312 (1985) 1217-1224. http://dx.doi.org/10.1056/NEJM198505093121903.

[4] D.S. Kelley, P.C. Taylor, G.J. Nelson, P.C. Schmidt, A. Ferretti, K.L. Erickson, R. Yu, R.K. Chandra, B.E. Mackey, Docosahexaenoic acid ingestion inhibits natural killer cell activity and production of inflammatory mediators in young healthy men, Lipids 34 (1999) 317-324.

[5] S.N. Meydani, S. Endres, M.M. Woods, B.R. Goldin, C. Soo, A. Morrill-Labrode, C.A. Dinarello, S.L. Gorbach, Oral (n-3) fatty acid supplementation suppresses cytokine production and lymphocyte proliferation: comparison between young and older women, J. Nutr. 121 (1991) 547-555.

[6] G.E. Caughey, E. Mantzioris, R.A. Gibson, L.G. Cleland, M.J. James, The effect on human tumor necrosis factor alpha and interleukin 1 beta production of diets enriched in n-3 fatty acids from vegetable oil or fish oil, Am. J. Clin. Nutr. 63 (1996) $116-122$.

[7] K.H. Baumann, F. Hessel, I. Larass, T. Müller, P. Angerer, R. Kiefl, C. von Schacky, Dietary omega-3, omega-6, and omega-9 unsaturated fatty acids and growth factor and cytokine gene expression in unstimulated and stimulated monocytes. A randomized volunteer study, Arterioscler. Thromb. Vasc. Biol. 19 (1999) 59-66.

[8] L.H. Sigal, Basic science for the clinician 39: NF-kappaB-function, activation, control, and consequences, J. Clin. Rheumatol. Pract. Rep. Rheum. Musculoskelet. Dis. 12 (2006) 207-211. http://dx.doi.org/10.1097/01.rhu.0000231385.94784.e4.

[9] E. Rigamonti, G. Chinetti-Gbaguidi, B. Staels, Regulation of macrophage functions by PPAR-alpha, PPAR-gamma, and LXRs in mice and men, Arterioscler. Thromb. Vasc. Biol. 28 (2008) 1050-1059. http://dx.doi.org/10.1161/ ATVBAHA.107.158998.

[10] M. Ricote, C.K. Glass, PPARs and molecular mechanisms of transrepression, Biochim. Biophys. Acta 2007 (1771) 926-935. http://dx.doi.org/10.1016/j.bbalip.2007.02.013.

[11] M.W. Buczynski, D.S. Dumlao, E.A. Dennis, Thematic review series: proteomics. An integrated omics analysis of eicosanoid biology, J. Lipid Res. 50 (2009) 1015-1038. http://dx.doi.org/10.1194/jlr.R900004-JLR200.

[12] G.L. Milne, Q. Dai, L.J. Roberts, The isoprostanes- -25 years later, Biochim Biophys. Acta 2015 (1851) 433-445. http://dx.doi.org/10.1016/j.bbalip.2014.10.007.

[13] L. Balas, M. Guichardant, T. Durand, M. Lagarde, Confusion between protectin D1 (PD1) and its isomer protectin DX (PDX). An overview on the dihydroxydocosatrienes described to date, Biochimie 99 (2014) 1-7. http://dx.doi.org/ 10.1016/j.biochi.2013.11.006.

[14] M. Gabbs, S. Leng, J.G. Devassy, M. Monirujjaman, H.M. Aukema, Advances in our understanding of oxylipins derived from dietary PUFAs, Adv. Nutr. 6 (2015) 513-540. http://dx.doi.org/10.3945/an.114.007732.

[15] J.-M. Galano, J.C.-Y. Lee, C. Gladine, B. Comte, J.-Y. Le Guennec, C. Oger, T. Durand, Non-enzymatic cyclic oxygenated metabolites of adrenic, docosahexaenoic, eicosapentaenoic and $\alpha$-linolenic acids; bioactivities and potential use as biomarkers, Biochim. Biophys. Acta 1851 (2015) 446-455. http://dx.doi.org/ 10.1016/j.bbalip.2014.11.004.

[16] S. Sethi, A.Y. Eastman, J.W. Eaton, Inhibition of phagocyte-endothelium interactions by oxidized fatty acids: a natural anti-inflammatory mechanism?, J. Lab. Clin. Med. 128 (1996) 27-38.

[17] C.N. Serhan, N. Chiang, J. Dalli, The resolution code of acute inflammation: novel pro-resolving lipid mediators in resolution, Semin. Immunol. 27 (2015) 200-215. http://dx.doi.org/10.1016/j.smim.2015.03.004.

[18] S. Sethi, O. Ziouzenkova, H. Ni, D.D. Wagner, J. Plutzky, T.N. Mayadas, Oxidized omega-3 fatty acids in fish oil inhibit leukocyte-endothelial interactions through activation of PPAR alpha, Blood 100 (2002) 1340-1346. http://dx.doi.org/ 10.1182/blood-2002-01-0316.

[19] A. Mishra, A. Chaudhary, S. Sethi, Oxidized omega-3 fatty acids inhibit NF-kappaB activation via a PPARalpha-dependent pathway, Arterioscler. Thromb. Vasc. Biol. 24 (2004) 1621-1627. http://dx.doi.org/10.1161/01.ATV.0000137191.02577.86.

[20] J. Lefils-Lacourtablaise, M. Socorro, A. Géloën, P. Daira, C. Debard, E. Loizon, M. Guichardant, Z. Dominguez, H. Vidal, M. Lagarde, N. Bernoud-Hubac, The eicosapentaenoic acid metabolite 15-deoxy- $\delta(12,14)$-prostaglandin J3 increases adiponectin secretion by adipocytes partly via a PPAR $\gamma$-dependent mechanism, PLoS One 8 (2013) e63997. http://dx.doi.org/10.1371/journal.pone.0063997.

[21] P.J. White, P.L. Mitchell, M. Schwab, J. Trottier, J.X. Kang, O. Barbier, A. Marette, Transgenic $\omega-3$ PUFA enrichment alters morphology and gene expression profile in adipose tissue of obese mice: potential role for protectins, Metabolism 64 (2015) 666-676. http://dx.doi.org/10.1016/j.metabol.2015.01.017.

[22] Y. Zhao, F. Calon, C. Julien, J.W. Winkler, N.A. Petasis, W.J. Lukiw, N.G. Bazan, Docosahexaenoic acid-derived neuroprotectin D1 induces neuronal survival via secretase- and PPAR $\gamma$-mediated mechanisms in Alzheimer's disease models, PLoS One 6 (2011) e15816. http://dx.doi.org/10.1371/journal.pone.0015816.

[23] G. Krey, O. Braissant, F. L'Horset, E. Kalkhoven, M. Perroud, M.G. Parker, W. Wahli, Fatty acids, eicosanoids, and hypolipidemic agents identified as ligands of peroxisome proliferator-activated receptors by coactivator-dependent receptor ligand assay, Mol. Endocrinol. Baltim. Md 11 (1997) 779-791. http://dx.doi.org/10.1210/ 
mend.11.6.0007.

[24] T. Itoh, L. Fairall, K. Amin, Y. Inaba, A. Szanto, B.L. Balint, L. Nagy, K. Yamamoto, J.W.R. Schwabe, Structural basis for the activation of PPARgamma by oxidized fatty acids, Nat. Struct. Mol. Biol. 15 (2008) 924-931.

[25] C. Gladine, J.W. Newman, T. Durand, T.L. Pedersen, J.-M. Galano, C. Demougeot, O. Berdeaux, E. Pujos-Guillot, A. Mazur, B. Comte, Lipid profiling following intake of the omega 3 fatty acid DHA identifies the peroxidized metabolites F4-neuroprostanes as the best predictors of atherosclerosis prevention, PLoS One 9 (2014) e89393. http://dx.doi.org/10.1371/journal.pone.0089393.

[26] E.S. Musiek, J.D. Brooks, M. Joo, E. Brunoldi, A. Porta, G. Zanoni, G. Vidari, T.S. Blackwell, T.J. Montine, G.L. Milne, B. McLaughlin, J.D. Morrow, Electrophilic cyclopentenone neuroprostanes are anti-inflammatory mediators formed from the peroxidation of the omega-3 polyunsaturated fatty acid docosahexaenoic acid, J. Biol. Chem. 283 (2008) 19927-19935. http://dx.doi.org/10.1074/ jbc.M803625200.

[27] C. Gladine, M. Zmojdzian, L. Joumard-Cubizolles, M.-A. Verny, B. Comte, A. Mazur, The omega-3 fatty acid docosahexaenoic acid favorably modulates the inflammatory pathways and macrophage polarization within aorta of LDLR(-/-) mice, Genes Nutr. 9 (2014) 424. http://dx.doi.org/10.1007/s12263-014-0424-4.

[28] H. Yin, E.S. Musiek, L. Gao, N.A. Porter, J.D. Morrow, Regiochemistry of neuroprostanes generated from the peroxidation of docosahexaenoic acid in vitro and in vivo, J. Biol. Chem. 280 (2005) 26600-26611. http://dx.doi.org/10.1074/ jbc.M503088200.

[29] G. Zanoni, E.M. Brunoldi, A. Porta, G. Vidari, Asymmetric synthesis of 14-A4tneuroprostane: hunting for a suitable biomarker for neurodegenerative diseases, J. Org. Chem. 72 (2007) 9698-9703. http://dx.doi.org/10.1021/jo701719f.

[30] C. Oger, V. Bultel-Poncé, A. Guy, L. Balas, J.-C. Rossi, T. Durand, J.-M. Galano, The handy use of Brown's P2-Ni catalyst for a skipped diyne deuteration: application to the synthesis of a [D4]-labeled F4t-neuroprostane, Chem. Weinh. Bergstr. Ger. 16 (2010) 13976-13980. http://dx.doi.org/10.1002/chem.201002304.

[31] G. Dayaker, T. Durand, L. Balas, A versatile and stereocontrolled total synthesis of dihydroxylated docosatrienes containing a conjugated E,E,Z-triene, Chem. Weinh. Bergstr. Ger. 20 (2014) 2879-2887. http://dx.doi.org/10.1002/chem.201304526.

[32] G. Chinetti, S. Griglio, M. Antonucci, I.P. Torra, P. Delerive, Z. Majd, J.C. Fruchart, J. Chapman, J. Najib, B. Staels, Activation of proliferator-activated receptors alpha and gamma induces apoptosis of human monocyte-derived macrophages, J. Biol. Chem. 273 (1998) 25573-25580.

[33] F.A. Fitzpatrick, W.F. Liggett, M.A. Wynalda, Albumin-eicosanoid interactions. A model system to determine their attributes and inhibition, J. Biol. Chem. 259 (1984) 2722-2727.

[34] E. Raspé, L. Madsen, A.M. Lefebvre, I. Leitersdorf, L. Gelman, J. Peinado-Onsurbe, J. Dallongeville, J.C. Fruchart, R. Berge, B. Staels, Modulation of rat liver apolipoprotein gene expression and serum lipid levels by tetradecylthioacetic acid (TTA) via PPARalpha activation, J. Lipid Res. 40 (1999) 2099-2110.

[35] T.J. Gray, B.G. Lake, J.A. Beamand, J.R. Foster, S.D. Gangolli, Peroxisome proliferation in primary cultures of rat hepatocytes, Toxicol. Appl. Pharmacol. 67 (1983) 15-25.

[36] J.M. Lehmann, L.B. Moore, T.A. Smith-Oliver, W.O. Wilkison, T.M. Willson, S.A. Kliewer, An antidiabetic thiazolidinedione is a high affinity ligand for peroxisome proliferator-activated receptor gamma (PPAR gamma), J. Biol. Chem. 270 (1995) 12953-12956.

[37] W.R. Oliver, J.L. Shenk, M.R. Snaith, C.S. Russell, K.D. Plunket, N.L. Bodkin, M.C. Lewis, D.A. Winegar, M.L. Sznaidman, M.H. Lambert, H.E. Xu, D.D. Sternbach, S.A. Kliewer, B.C. Hansen, T.M. Willson, A selective peroxisome proliferatoractivated receptor delta agonist promotes reverse cholesterol transport, Proc. Natl. Acad. Sci. USA 98 (2001) 5306-5311. http://dx.doi.org/10.1073/pnas.091021198.

[38] B. Staels, W. Koenig, A. Habib, R. Merval, M. Lebret, I.P. Torra, P. Delerive, A. Fadel, G. Chinetti, J.C. Fruchart, J. Najib, J. Maclouf, A. Tedgui, Activation of human aortic smooth-muscle cells is inhibited by PPARalpha but not by PPARgamma activators, Nature 393 (1998) 790-793. http://dx.doi.org/10.1038/ 31701.

[39] C.N. Serhan, K. Gotlinger, S. Hong, Y. Lu, J. Siegelman, T. Baer, R. Yang, S.P. Colgan, N.A. Petasis, Anti-inflammatory actions of neuroprotectin D1/protectin D1 and its natural stereoisomers: assignments of dihydroxy-containing docosatrienes, J. Immunol. 176 (2006) 1848-1859.

[40] J.M. Schwab, N. Chiang, M. Arita, C.N. Serhan, Resolvin E1 and protectin D1 activate inflammation-resolution programmes, Nature 447 (2007) 869-874. http:// dx.doi.org/10.1038/nature05877.

[41] S. Hong, H. Tian, Y. Lu, J.M. Laborde, F.A. Muhale, Q. Wang, B.V. Alapure, C.N. Serhan, N.G. Bazan, Neuroprotectin/protectin D1: endogenous biosynthesis and actions on diabetic macrophages in promoting wound healing and innervation impaired by diabetes, Am. J. Physiol. Cell Physiol. 307 (2014) C1058-C1067. http://dx.doi.org/10.1152/ajpcell.00270.2014.

[42] B. Díez-Dacal, D. Pérez-Sala, Anti-inflammatory prostanoids: focus on the interactions between electrophile signaling and resolution of inflammation, Sci. World J.
10 (2010) 655-675. http://dx.doi.org/10.1100/tsw.2010.69.

[43] J. Roy, C. Oger, J. Thireau, J. Roussel, O. Mercier-Touzet, D. Faure, E. Pinot, C. Farah, D.F. Taber, J.-P. Cristol, J.C.Y. Lee, A. Lacampagne, J.-M. Galano, T. Durand, J.-Y. Le Guennec, Nonenzymatic lipid mediators, neuroprostanes, exert the antiarrhythmic properties of docosahexaenoic acid, Free Radic. Biol. Med. 86 (2015) 269-278. http://dx.doi.org/10.1016/j.freeradbiomed.2015.04.014.

[44] P.J. White, P. St-Pierre, A. Charbonneau, P.L. Mitchell, E. St-Amand, B. Marcotte, A. Marette, Protectin DX alleviates insulin resistance by activating a myokine-liver glucoregulatory axis, Nat. Med. 20 (2014) 664-669. http://dx.doi.org/10.1038/ nm.3549.

[45] P. Chen, E. Véricel, M. Lagarde, M. Guichardant, Poxytrins, a class of oxygenated products from polyunsaturated fatty acids, potently inhibit blood platelet aggregation, FASEB J. Off. Publ. Fed. Am. Soc. Exp. Biol. 25 (2011) 382-388. http:// dx.doi.org/10.1096/fj.10-161836.

[46] M. Liu, T. Boussetta, K. Makni-Maalej, M. Fay, F. Driss, J. El-Benna, M. Lagarde, M. Guichardant, Protectin DX, a double lipoxygenase product of DHA, inhibits both ROS production in human neutrophils and cyclooxygenase activities, Lipids 49 (2014) 49-57. http://dx.doi.org/10.1007/s11745-013-3863-6.

[47] J.C. Masterson, E.N. McNamee, S.A. Fillon, L. Hosford, R. Harris, S.D. Fernando, P. Jedlicka, R. Iwamoto, E. Jacobsen, C. Protheroe, H.K. Eltzschig, S.P. Colgan, M. Arita, J.J. Lee, G.T. Furuta, Eosinophil-mediated signalling attenuates inflammatory responses in experimental colitis, Gut 64 (2015) 1236-1247. http:// dx.doi.org/10.1136/gutjnl-2014-306998.

[48] S. Li, Y. Zhu, J.E. Chavarro, W. Bao, D.K. Tobias, S.H. Ley, J.P. Forman, A. Liu, J. Mills, K. Bowers, M. Strøm, S. Hansen, F.B. Hu, C. Zhang, Healthful dietary patterns and the risk of hypertension among women With a history of gestational diabetes mellitus: a prospective cohort study, Hypertension 67 (2016) 1157-1165 http://dx.doi.org/10.1161/HYPERTENSIONAHA.115.06747.

[49] J.S. Duffield, S. Hong, V.S. Vaidya, Y. Lu, G. Fredman, C.N. Serhan, J.V. Bonventre, Resolvin D series and protectin D1 mitigate acute kidney injury, J. Immunol. 177 (2006) 5902-5911.

[50] A. Ariel, P.-L. Li, W. Wang, W.-X. Tang, G. Fredman, S. Hong, K.H. Gotlinger, C.N. Serhan, The docosatriene protectin D1 is produced by TH2 skewing and promotes human T cell apoptosis via lipid raft clustering, J. Biol. Chem. 280 (2005) 43079-43086. http://dx.doi.org/10.1074/jbc.M509796200.

[51] S. Hong, K. Gronert, P.R. Devchand, R.-L. Moussignac, C.N. Serhan, Novel docosatrienes and 17S-resolvins generated from docosahexaenoic acid in murine brain, human blood, and glial cells. Autacoids in anti-inflammation, J. Biol. Chem. 278 (2003) 14677-14687. http://dx.doi.org/10.1074/jbc.M300218200.

[52] W.J. Lukiw, J.-G. Cui, V.L. Marcheselli, M. Bodker, A. Botkjaer, K. Gotlinger, C.N. Serhan, N.G. Bazan, A role for docosahexaenoic acid-derived neuroprotectin D1 in neural cell survival and Alzheimer disease, J. Clin. Investig. 115 (2005) 2774-2783. http://dx.doi.org/10.1172/JCI25420.

[53] N.K. Rajasagi, P.B.J. Reddy, S. Mulik, P. Gjorstrup, B.T. Rouse, Neuroprotectin D1 reduces the severity of herpes simplex virus-induced corneal immunopathology, Investig. Ophthalmol. Vis. Sci. 54 (2013) 6269-6279. http://dx.doi.org/10.1167/ iovs.13-12152.

[54] V.L. Marcheselli, S. Hong, W.J. Lukiw, X.H. Tian, K. Gronert, A. Musto, M. Hardy, J.M. Gimenez, N. Chiang, C.N. Serhan, N.G. Bazan, Novel docosanoids inhibit brain ischemia-reperfusion-mediated leukocyte infiltration and pro-inflammatory gene expression, J. Biol. Chem. 278 (2003) 43807-43817. http://dx.doi.org/10.1074/ jbc.M305841200.

[55] M.S. Cortina, J. He, T. Russ, N.G. Bazan, H.E.P. Bazan, Neuroprotectin D1 restores corneal nerve integrity and function after damage from experimental surgery, Investig. Ophthalmol. Vis. Sci. 54 (2013) 4109-4116. http://dx.doi.org/10.1167/ iovs.13-12075.

[56] V.I. Lushchak, Dissection of the hormetic curve: analysis of components and mechanisms, Dose-Response Publ. Int. Hormesis Soc. 12 (2014) 466-479. http:// dx.doi.org/10.2203/dose-response.13-051.Lushchak.

[57] V.L. Marcheselli, P.K. Mukherjee, M. Arita, S. Hong, R. Antony, K. Sheets, J.W. Winkler, N.A. Petasis, C.N. Serhan, N.G. Bazan, Neuroprotectin D1/protectin D1 stereoselective and specific binding with human retinal pigment epithelial cells and neutrophils, Prostaglandins Leukot. Essent. Fat. Acids 82 (2010) 27-34. http:// dx.doi.org/10.1016/j.plefa.2009.10.010.

[58] S. Hong, Y. Lu, Omega-3 fatty acid-derived resolvins and protectins in inflammation resolution and leukocyte functions: targeting novel lipid mediator pathways in mitigation of acute kidney injury, Front. Immunol. 4 (2013) 13. http://dx.doi.org/ 10.3389/fimmu.2013.00013.

[59] S. Kersten, B. Desvergne, W. Wahli, Roles of PPARs in health and disease, Nature 405 (2000) 421-424. http://dx.doi.org/10.1038/35013000.

[60] B. Vergès, Clinical interest of PPARs ligands, Diabetes Metab. 30 (2004) 7-12.

[61] K. Stamatakis, D. Pérez-Sala, Prostanoids with cyclopentenone structure as tools for the characterization of electrophilic lipid-protein interactomes, Ann. N.Y. Acad. Sci. 1091 (2006) 548-570. http://dx.doi.org/10.1196/annals.1378.096. 